\title{
Anatomy and Histology of Testes of Male Buffalo Egrets (Bubulcus Ibis)
}

\author{
Lita Ayu Umartani, Aretasani Rahim, Halimah Asy Syahidah* \\ Biology Department, Faculty of Science and Technology, UIN Sunan Kalijaga \\ Jl. Marsda Adisucipto No 1 Yogyakarta 55281, Indonesia. Tel. +62-274-540971, Fax. +62-274-519739 \\ "Email: halimahasysyahidah23@gmail.com
}

\begin{abstract}
The buffalo egret (Bubulcus ibis) belongs to the Ciconiiformes order, family Ardeidae. The buffalo egret (Bubulcus ibis) is the smallest egret (about $50 \mathrm{~cm}$ ). Its body is slimmer than Blekoksawah (Ardeolaspeciosa), although not as large as egrets. All feathers are white, but during the mating season the feathers on the head, neck, back and chest are yellow. Reproductive organs are the key to success in maintaining new offspring. Male reproductive organs will produce male sex cells or living spermatozoa. It is important to do research on anatomy and histology to determine the maturity of the reproductive organs of the bird. The purpose of this study was to determine the anatomical and histological structure of male reproductive organs of buffalo egrets (Bubulcus ibis). The method used for histology is the paraffin method with Hematoxylin-Eosin staining. The data analysis technique uses descriptive analysis for histological preparations. Anatomical observations include the color, shape and location of the reproductive organs, while histological observations of the structure of the reproductive organs using a microscope. The results of the study were anatomically pale-colored testicle. The location of the testicles is on ventral from the most cranial lobe. While the histological structure of the testis of the Buffalo Egret (Bubulcus ibis) consisted of spermatozoa, lumen, stereosilia, ephitelium of eididymis and seminiferous tubules.
\end{abstract}

Keywords: Anatomy, Bubulcus ibis, Testicles

\section{INTRODUCTION}

Indonesia has a variety of bird species, one of them is the Buffalo Egret (Bubulcus ibis). The Buffalo Egret (Bubulcus ibis) is one of the birds of the ciconiiformes order of Ardeidae family. The buffalo egret (Bubulcus ibis) is the smallest bird of the herons (about $50 \mathrm{~cm}$ ). The bird likes to look for food in areas of rice fields that have just been planted. His body shape is slimmer than Blekoksawah (Ardeolaspeciosa), although not as large egrets. All feathers are white, but during the mating season, the feathers on the head, neck, back and chest are yellow (Biodiversitas Indonesia, 2012).

In general, ciconiiformes are carnivores. In the rice fields the Bubulcus ibis is useful as a control for insect pests and as a seasonal change by farmers. However, in fish or shrimp aquaculture areas, Bubulcus ibis can be a pest for farmers because it can eat fish or shrimp excessively. As a result of habitat loss (paddy field into housing), poaching, catching for pet birds and the use of pesticides (pollution: water, soil, and air), cause human own harm (Gale, 2005). The species of buffalo herons is now diminishing and is beginning to be threatened and can lead to extinction.

Buffalo herons according to International Union Conservation Nature (IUCN) data as of Least Concern (LC) since 2004, 2008, 2009 and until now, and listed on the basis of the legal protection of the Unitary State of the Republic of Indonesia (NKRI) in government regulation No. 5/1990 concerning Conservation of Living Natural Resources and their Ecosystems (Winnasis et al., 2009). In 1991, Indonesia ratified the Wetland Convention on wetlands that have international interests, especially as water bird habitat. Each member country has the right to submit certain wetland locations that have met the specified criteria, as wetlands that have international interests and then make and carry out a management plan for the area and the resources in it. This will support the protection and preservation of water birds, including one of the buffalo herons (Bubulcus ibis) (Howes et al., 2003).

Reproductive organs are the key to success in maintaining new offspring. Male reproductive organs will produce male sex cells or living spermatozoa. Research on the anatomy and histology of the reproductive organs is important to determine the maturity of the reproductive organs namely testes. Given that each species has a different reproductive structure such as the reproductive tract anatomical structure that will be closely related to the physiological functions of the organs in the species (Phadmacanty et al., 2013). It is important to study its biological aspects so that it can be used for future needs, especially in an effort to preserve bird species. So far there has been no study of organ anatomy and histology male reproduction of the Bubulcus ibis species. Therefore it is interesting to examine the anatomy and histology of the buffalo egret testes (Bubulcus ibis).

\section{MATERIALS AND METHODS}

This research used male egrets (Bubulcus ibis) which were found around the rice fields. First the male egrets are sedated using a chloroform in a box without ventilation. The animal dissected topography of reproductive organs was photographed, cleaned with $0.9 \% \mathrm{NaCl}$, then put in bottles containing bouin for 24 hours. After being left in the bouin solution, the organs 
washed with water flow for 15 minutes, do dehydration by immersing the organs in to alcohol of $20 \%, 30 \%$, 40\%, 50\%, 60\%, 70\%, 80\%, 90\%, 100\% absolute). Testes clearing was done by soaking the organ in to toluene for 12 hours and then embedding it in paraffin blocks. After that the paraffin was cut and deparafinized using xylol I, xylol II, xylol III for 5 minutes. Then put in absolute alcohol I and absolute alcohol II for 5 minutes, then put in to aquadest for 1 minute. Next put in Hematoxylin dye for 30, washed in running water flow for 1 minute then aquadest for 15 minutes and put in to eosin for 10 minutes. Next put in 96\% alcohol 1, 96\% alcohol 2, absolute alcohol 3 and absolute alcohol 4 each for 3 minutes. Then put in xylol 4 and xylol 5 for 5 minutes. Then the mounting was done by the dripping the bowles on the glass object until there are no bubbles left.

\section{RESULT AND DISCUSSION}

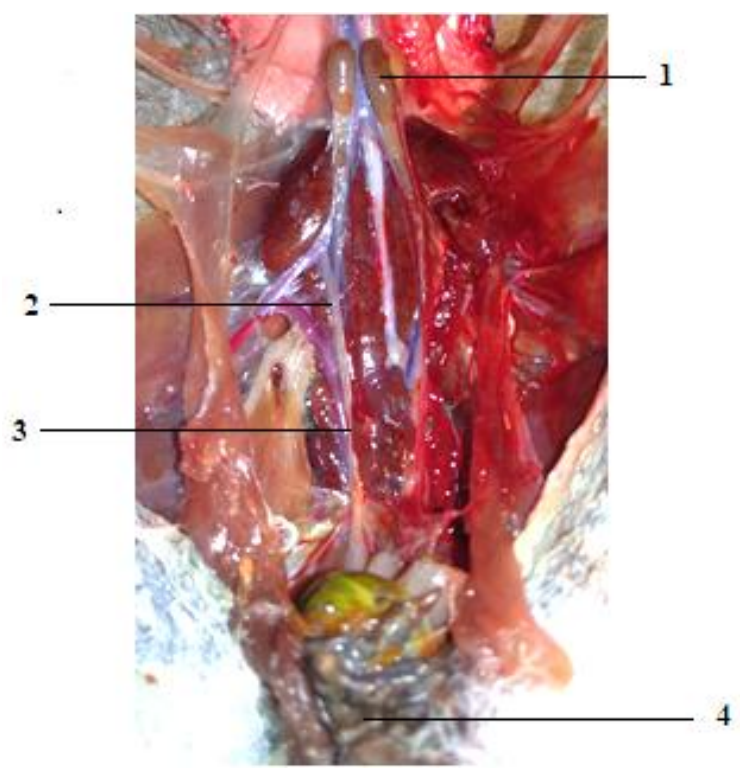

Figure 1. Structure anatomy of Egret (Bubulcus ibis) testicles. (1) Testicles, (2) Epididymis, (3) Ureter, (4) Cloaca.

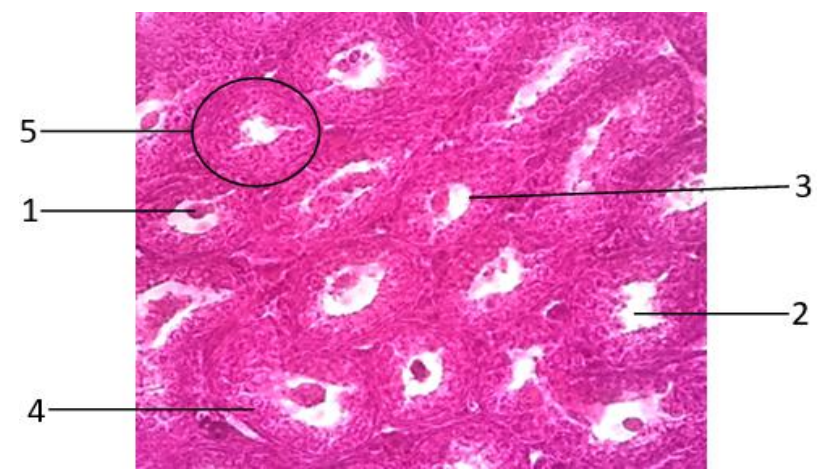

Figure 2. Cross section of egret testis histology. (1) Spermatozoa in lumen, (2) Lumen of epididymis, (3) Stereocilia, (4) Epithelium of the epididymis, (5) Seminiferous tubule.
In general, birds have a urogenital system in the form of a pair of pale testicles, the size of an ovalshaped soy bean and located ventrally from the most cranial lobe. There are a pair of channels that channel the spermatozoa to the ductus deferens which is located on the dorsal side of the testes and is called the epididymis. A pair of ductus deferens that travel across the ureter, then empties into the lateral cloaca (Radiopoetro, 1977).

Based on observations made, there are spermatozoa that form in the lumen in the testis. The position of spermatogonia is in the basal layer of the seminiferous tubules. Spermatogonia continues to divide to multiply. Some of spermatogonia differentiate through certain stages of development to form spermatozoa. The spermatozoa formed indicate that the specimen being sampled has undergone maturation. Maturation in birds can be seen from greater body weight, color changes in bird feathers, has a yellow beak, and has a more melodious chirping sound that can attract the attention of the opposite sex (Rosinska, 2007). A bird that has grown up can show behavior that indicates that it has entered a period of breeding or marriages as Wing Preening and Head Flicks to the female who exercised her discretion of selecting the appropriate male by peering at him with her neck extended thereby leading to the pair formation, sometimes do courtship flight to attract the attention of the opposite sex or one of the opposite sex will play tickle his partner (Mckilligan, 2005). The collection of specimens carried out in March can be assumed that in that month the egrets are experiencing session breeding, this is in accordance with the statement of (Patankar et al., 2007) that sesion breeding in egrets occurred in March to July.

According to Iriyono (2017), egrets have morphological characteristics, namely smaller body size of about $50 \mathrm{~cm}$, has a bird feathers are white with a wash of orange on the forehead area for egrets buffalo that are not in a breed, while egrets buffalo that are in bloom so it will have the color of orange feathers disappear on the head, neck and chest. The characteristics of buffalo herons during this breeding period are the same as bird specimens used in this study.

\section{CONCLUSIONS}

Based on research and observations made, it can be concluded that the anatomical structure of the testespale-colored testicle, the size of an oval-shaped soy bean and located ventrally from the most cranial lobe. While the histological structure of the testis of the Buffalo Egret (Bubulcus ibis) consisted of spermatozoa, lumen, stereosilia, ephitelium of eididymis and seminiferous tubules. Can be seen there are spermatozoa that form in the lumen in the testis. The spermatozoa formed indicate that the specimen being sampled has undergone maturation. That the 
egrets are made in the specimen in this trial really has undergone maturation and sperm contained in testicular histology observed egrets.

\section{ACKNOWLEDGMENTS}

The author would like to thank to the management of apprenticeship program of faculty of science and technology for guidance during the research, to the management of biology, medicine and natural product chemistry \& kaunia journal for assistance in paper writing.

\section{REFERENCES}

Gale, T. 2005. Grzimek's student animal life resource volume 1 birds.

Howes,J.,D.Bakewell, \& Y.R. Noor. 2003. Panduan studi burung pantai.
Iriyono, S., Rd. Rifki M. S., Vitriana Y. M., Eri M., Nur S., Hayunieta. 2017. Habitat Satwa Dilindungi, Kuntul Kerbau (Bubulcus ibis) yang Semakin Terdesak Pembangunan di Kota Bandung. Bandung: Balai Besar Konservasi Sumber Daya Alam Jawa Barat

Mckilligan N. G., (1990), Promiscuity in the Cattle Egret (Bubulcus ibis), The Auk, 107, pp 334-341.

Patankar P., Desai I., Shinde K., and Suresh B. (2007). Ecology and breeding biology of the Cattle Egret (Bubulcus ibis) in an industrial area at Vadodra, Gujarat, Zoos' Print Journal, 22(11), pp 2885-2888.

Phadmacanty, R.P.N., Nugraha, P.T.R \&Wirdateti. 2013 Reproductive Organ of Male Sulawesi Giant Rat (Paruromys dominator). Sains Veteriner,31 (1), 0126 - 0421.

Radiopoetro. 1977. Zoology. Erlangga: Jakarta.

Rosiñska K. 2007. Biometrics and morphology variation within sexage groups of Robins (Erithacus rubecula) migrating through the Polish Baltic coast. Ring 29 (1-2) : 91-106.

Winnasis, S., A. Toha, danSutadi. 2009. Burung-Burung Taman Nasional Baluran. Balai Taman Nasional Baluran: Situbondo. 
THIIS PAGE INTENTIONALLY IEIT BLANK 